\title{
Hva bidrar til at \\ sykepleiere utvikler sin kompetanse?
}

\section{Å delta i en refleksjonsgruppe på arbeidsplassen kan være viktigere for den faglige utviklingen enn videreutdanning og kurs.}

Inger-Johanne Thidemann

Førstelektor

Institutt for helse- og sykepleievitenskap, Universitetet i Agder, Campus Grimstad

Hans Inge Sævareid

Førsteamanuensis

Institutt for helse- og sykepleievitenskap, Universitetet i Agder, Campus Grimstad

Åshild Slettebø

Professor

Institutt for helse- og sykepleievitenskap, Universitetet i Agder, Campus Grimstad

Arbeidsmiljø Kunnskapsbasert sykepleie Veiledning

Sykepleien 2020108 (82269) (e-82269)

DOI: 10.4220/Sykepleiens.2020.82269

\section{Hovedbudskap}

Gjennom tre studier har forskerne fulgt et kull sykepleiere og unders $\varnothing \mathrm{kt}$ hva som fremmer læring og utvikling av sykepleiefaglig kompetanse. Det er mer enn 20 år siden disse sykepleierne tok sin utdanning. Sykepleierne gir uttrykk for at å delta i en sykepleiefaglig veiledningsgruppe, der de reflekterer sammen med engasjerte kolleger i et støttende arbeidsmiljø, er svært lærerikt og har stor betydning for utviklingen av deres faglige kompetanse. 
Et kull sykepleierstudenter og sykepleiere har deltatt i et forskningsprosjekt som har unders $\varnothing \mathrm{kt}$ hva som fremmer læring og utvikling av sykepleiefaglig kompetanse under sykepleierstudiet og senere i yrkespraksisen. Det er nå mer enn 20 år siden disse sykepleierne tok sin utdanning. Forskningsprosjektet har pågått i tre studier (1-5) (Tabell 1).

Hva skjedde med sykepleierne i dette kullet etter at de var ferdig med utdanningen, og hvilke valg tok de for å videreutvikle sin sykepleiefaglige kompetanse i klinisk praksis over en periode på mer enn 20 år?

Disse spørsmålene ble starten på studie fire, som er en studie med kombinerte metoder: en kvantitativ spørreskjemaundersøkelse (se tabell 1) og dybdeintervju med åtte sykepleiere fra samme kull. Spørreskjemaet ble analysert med deskriptiv statistikk og de kvalitative intervjuene med kvalitativ innholdsanalyse (6).

Tabell 1. Design og metoder i den longitudinelle studien fra student til erfaren sykepleier

\begin{tabular}{|c|c|c|c|}
\hline Tidsperiode & Problemstilling & $\begin{array}{l}\text { Metode } \\
\text { NSD-prosjektnr. }\end{array}$ & $\begin{array}{l}\text { Respondenter } \\
\text { og informanter }\end{array}$ \\
\hline $\begin{array}{l}\text { Studie 1: } \\
\text { Under sykepleier- } \\
\text { studiet }\end{array}$ & $\begin{array}{l}\text { Sykepleierstudiet } \\
\text { Hvordan bør studiet tilrettelegges for } \\
\text { å gi størst mulig grad av faglig kontinuitet } \\
\text { og progresjon i læringsprosessen? }\end{array}$ & $\begin{array}{l}\text { Spørreskjema etter de } \\
\text { kliniske praksisperiodene. } \\
\text { NSD: } 2654\end{array}$ & 62 studenter \\
\hline $\begin{array}{l}\text { Studie 2: } \\
\text { Tre år etter avsluttet } \\
\text { grunnutdanning i } \\
\text { sykepleie }\end{array}$ & $\begin{array}{l}\text { Med bakgrunn i dine erfaringer som sykepleier: } \\
\text { Hvilke faktorer har og har hatt betydning for } \\
\text { kompetanseutviklingen din etter avsluttet } \\
\text { grunnutdanning i sykepleie? }\end{array}$ & $\begin{array}{l}\text { Spørreskjema NSD: } \\
1198-2654\end{array}$ & $\begin{array}{l}52 \text { sykepleiere: } \\
\text { svarprosent er } 84 \%\end{array}$ \\
\hline $\begin{array}{l}\text { Studie 3: } \\
\text { Fem år etter avsluttet } \\
\text { grunnutdanning i } \\
\text { sykepleie }\end{array}$ & $\begin{array}{l}\text { Med bakgrunn i dine erfaringer som sykepleier: } \\
\text { Hvilke faktorer har og har hatt betydning for } \\
\text { kompetanseutviklingen din etter avsluttet } \\
\text { grunnutdanning i sykepleie? }\end{array}$ & $\begin{array}{l}\text { Dybdeintervju av et } \\
\text { strategisk utvalg fra studie } 2 . \\
\text { NSD: } 2858\end{array}$ & 9 sykepleiere \\
\hline $\begin{array}{l}\text { Studie 4, } \\
\text { del I og del II: } \\
20 \text { år etter avsluttet } \\
\text { grunnutdanning i } \\
\text { sykepleie }\end{array}$ & $\begin{array}{l}\text { Hvilke faktorer har og har hatt betydning } \\
\text { for sykepleiernes læring og kompetanse- } \\
\text { utvikling i et } 20 \text {-årsperspektiv? } \\
\text { En kartlegging og beskrivelser av erfarne } \\
\text { sykepleieres erfaringer. }\end{array}$ & $\begin{array}{l}\text { Del I: } \\
\text { Spørreskjema } \\
\text { Del II: } \\
\text { Dybdeintervju } \\
\text { NSD: } 51299\end{array}$ & $\begin{array}{l}\text { Del I: } \\
41 \text { sykepleiere: } \\
\text { svarprosent er } 70 \% \\
\text { Del II: } \\
8 \text { sykepleiere }\end{array}$ \\
\hline
\end{tabular}

\section{Hensikten med studien}

Hensikten med studien var å få kunnskap om

problemstillingen: Hvilke faktorer har og har hatt betydning for sykepleieres læring og kompetanseutvikling i et tidsperspektiv på mer enn 20 år? Forskningsspørsmålene var: Hvordan skjer læring og utvikling av sykepleiefaglig kompetanse blant erfarne sykepleiere? Hva kan vi lære av deres erfaringer? 


\section{Hva er kompetanse?}

Kompetanse er knyttet til kvalitet, pasientsikkerhet, arbeidsmiljø og ressursbruk. Lai (7) har gitt følgende definisjon av kompetansebegrepet: «Kompetanse er de samlede kunnskaper, ferdigheter, evner og holdninger som gjør det mulig å utføre aktuelle oppgaver i tråd med definerte krav og mål» (7, s. 46).

Kompetansekomponentene er forankret hos enkeltindivider (7). Utfordringen er hvordan den enkelte sykepleier kan forvalte, videreutvikle og mobilisere kompetansen sin, slik at de ulike arbeidsplassene kan nå sine definerte krav og mål.

\section{Sykepleiere får ekspertkompetanse}

Benner (8) beskriver hvordan nyutdannede sykepleiere gradvis opparbeider seg ekspertkompetanse i fem trinn.

Kjennetegn på ekspertsykepleieren er at sykepleieren har en god og helhetlig klinisk forståelse og får raskt et intuitivt grep om situasjoner. Ekspertsykepleieren har «vite hvordan»kunnskap, som er erfaringskunnskap og kjennetegn på et mestringsnivå som er ervervet gjennom lang erfaring og med refleksjon over erfaringene (8).

\section{三 $\ll$ Medlemmene $[. .$.$] lærer ved å delta i handlinger i$ praksisfellesskapet.»}

Lave og Wengers (9) teori om situert læring (læring som skjer eller tar plass i en helt bestemt sosiokulturell ramme) representerer også et relasjonelt syn på læring. Det viktigste elementet i teorien er praksisfellesskapet mellom kolleger. Medlemmene får tilgang til kunnskap og lærer ved å delta i handlinger i praksisfellesskapet.

\section{Sykepleierne utsettes for medfølelsesutmattelse}

Når sykepleiere arbeider med sårbare pasienter over tid, og har en sterk empatisk holdning til pasientene, men uten å få nødvendig støtte, kan det medføre at sykepleierne utsettes for medfølelsesutmattelse (compassion fatigue). Medfølelsesutmattelse er definert som «the formal caregiver's reduced capacity or interest in being empathic or bearing the suffering of clients» (10, s. 103). 
Figley (11) uttrykker det slik: «There is a cost to caring. Professionals who listen to clients`stories of fear, pain, and suffering may feel similar fear, pain, and suffering because they care. Sometimes we feel we are losing our own sense of self to the clients we serve» (11, s. 18).

\section{Hvordan skjer læring og kompetanseutvikling?}

Studien viser at læring og utvikling av kompetanse som erfaren sykepleier primært skjer i praksisfellesskapet sammen med kolleger (85 prosent) og gjennom refleksjoner over eget arbeid (82 prosent).

Det er viktig å legge merke til at de faktorene som angår faglig virksomhet; eget- og kollegers faglige engasjement, støttende arbeidsmilj $\varnothing$, direkte arbeid med pasienter og selvstendig yrkesut $\varnothing$ velse ble ansett som de viktigste faktorene for læring og utvikling av kompetanse (tabell 2). Dette representerer motiverende og emosjonell atferd.

\section{三 $\ll$ For disse erfarne sykepleierne har relasjonelle og reflekterende forhold større betydning enn kurs eller tid til faglig fordypning.»}

En ser altså at for disse erfarne sykepleierne har relasjonelle og reflekterende forhold større betydning enn tilrettelegging av kurs eller avsatt tid til faglig fordypning. Dette tyder på at disse sykepleierne har et mestringsnivå som er ervervet gjennom lang erfaring og med refleksjon over erfaringene (8).

De $\varnothing$ vrige svaralternativene representerer organiserte tiltak/tilrettelegging og rangeres som mindre betydningsfulle for læring og utvikling av kompetanse enn de faktorene som angår faglig virksomhet.

Selv om for eksempel faglige veiledningsgrupper i den kvalitative studien understrekes som vesentlig tiltak på en arbeidsplass, er det ikke selve tids-ressursen i arbeidsplanen som vektlegges mest i denne studien, men de positive faglige, relasjonelle og emosjonelle læreprosesser som gjerne skjer i en veiledningsgruppe. 


\section{Studentene etterspurte veiledningsgrupper}

Funn fra tidligere studier, da respondentene var

sykepleierstudenter og nyutdannede sykepleiere (tabell 1, delstudiene: 1-2), viser at studenter som deltok i

sykepleiefaglige veiledningsgrupper under studiet etterspurte dette i sin yrkespraksis som nyutdannede sykepleiere (3). Det var fordi de anså det som nyttig og verdifullt for egen læring og sykepleiefaglige kompetanseutvikling (1-3).

Tabell 2. Betydningsfulle faktorer for læring og utvikling av kompetanse

\begin{tabular}{lr} 
& Antall \\
& $\mathrm{N}=38$ \\
\hline & $\mathrm{N}(\%)$ \\
\hline Eget faglige engasjement & $34(90)$ \\
Faglig engasjerte kolleger & $32(84)$ \\
Støttende arbeidsmiljø & $27(71)$ \\
Direkte arbeid med pasienter & $27(71)$ \\
Stor grad av selvstendighet i arbeidet & $26(68)$ \\
Faglig engasjert(e) leder(e) & $24(63)$ \\
Organisert opplæring og kurs utenfor arbeidsstedet & $20(53)$ \\
Formell videreutdanning i sykepleie og etterutdanning & $19(50)$ \\
Organiserte kurs på arbeidsstedet & $18(47)$ \\
Organisert opplæring på arbeidsstedet & $13(34)$ \\
Mulighet for å drive med fagutviklings- og/eller forskningsarbeid & $6(16)$ \\
Avsatt tid i turnus/arbeidsplan til å delta i faglig veiledningsgruppe & $4(11)$ \\
Avsatt tid i turnus/arbeidsplan til faglig ajourføring/fordypning & $3(8)$ \\
Annet & $3(8)$
\end{tabular}

Tre svarte ikke på spørreskjemaet

Flere av faktorene som kom frem i den kvantitative kartleggingsunders $\varnothing$ kelsen (tabell 2) ble vektlagt og utdypet i intervjuene. Intervjuunders $\varnothing$ kelsen synliggjorde fire sentrale temaer knyttet til lærings- og kompetanseutviklingsprosessen siden forrige intervju for cirka 15 år siden.

\section{Opparbeidelse av erfaring - to utfordrende prosesser}

I intervjuene forteller sykepleierne om to sentrale prosesser som en følge av usikkerhet og engstelse som nyutdannet sykepleier. Sju av sykepleierne bruker begreper som frykt, angst, redd, livredd, vettskremt, gruet seg eller følte seg uvel.

Opplevelsen av økt trygghet og redusert usikkerhet kom gradvis med $\varnothing \mathrm{kt}$ erfaring. Sykepleierne forteller om en bratt læringskurve som nyutdannet, og hvor frykten for å feile var sterkt til stede $(2,5)$. 
De to primære målene som nyutdannet var å få økt klinisk erfaring for å utvide repertoaret sitt i forhold til det kliniske blikket og deretter prosessen med å stole på sine erfaringer. Flere poengterer at læring også handler om hvor reflektert du jobber med de erfaringene som du får. Informantene kaller dette erfaringsbygging.

\section{En sykepleier forteller om et trygt arbeidsmiljø}

En sykepleier forteller om sine positive erfaringer fra sitt første arbeidssted i et trygt og støttende arbeidsmiljø:

«Som nyutdannet sykepleier hadde jeg min første jobb ved et sted hvor jeg fikk veldig mye mengdetrening. Jeg fikk og sa ja til mange oppgaver og fikk mye ansvar. Og det kunne jeg gjøre fordi jeg hadde god opplæring og jobbet med dyktige kolleger. De var faglig trygge, de så meg, de tålte at jeg stilte spørsmål, de ville ha spørsmål og ønsket å dele kunnskapen sin med meg. Da lærer en hverandre å kjenne, og blir faglig trygge på hverandre. Man lærer raskt og kommer fort inn i ulike problemstillinger fordi man står sammen i arbeidsfellesskapet.»

Informantene, som i dag er erfarne sykepleiere, presiserer at en aldri blir utlært som sykepleier, men en blir tryggere med årene og gjennom de erfaringene en får. De erfarne sykepleierne var svært bevisste på at nyutdannede sykepleiere skulle få delta i dialoger når de, som erfarne sykepleiere, analyserte, vurderte og reflekterte over pasientsituasjoner.

\section{Et støttende arbeidsmiljø er viktig}

Det viktigste for sykepleierne, fra de var nyutdannet til erfarne, var å være en del av et praksisfellesskap med faglig engasjerte kolleger i et st $\varnothing$ ttende arbeidsmiljø (tabell 2).

Resultatene viser at i et st $\varnothing t t e n d e$ arbeidsmilj $\varnothing$ får man etter hvert stor grad av selvstendighet i arbeidet og $\varnothing \mathrm{kt}$ ansvar. Det førte igjen til at sykepleierne ble motiverte og ønsket å lære mer. En informant uttrykker seg slik:

«Det åpner opp for læring fordi du tenker: dette må jeg virkelig sette meg godt inn i. Så opplever en etter hvert at en blir faglig mer trygg i jobben. I en travel hverdag er det aller viktigste arbeidsmiljøet. Det at du føler at det er trygt, og at du jobber sammen med gode kolleger. Da tåler du veldig mye mer av stress og mas.» 


\section{«Et støttende arbeidsmiljø er kjennetegnet av at sykepleierne blir sett og verdsatt.»}

Et st $\varnothing$ ttende arbeidsmiljø er kjennetegnet av at sykepleierne blir sett og verdsatt av hverandre og faglig ledelse. Gjennom dialoger, erfarings- og kunnskapsutveksling, etiske og faglige refleksjoner, ved å gi anerkjennelse, være inkluderende og ved å fremsnakke hverandre utvikles et støttende arbeidsmiljø preget av gjensidig respekt, tillit, trygghet og samhold.

Studien viser at i slike miljøer får man en opplevelse av at en vil hverandre vel. Da er man også bedre rustet til å tåle stress og utfordringer, ifølge sykepleierne. Studien viser også at arbeidsgiveren, gjennom faglig ledelse, har en sentral rolle for å skape et st $\varnothing t t e n d e ~ a r b e i d s m i l j \varnothing$.

\section{Ydmykhet bygger tillit}

Grunnleggende for de erfarne sykepleierne og deres læring og kompetanseutvikling relatert til direkte arbeid med pasienter (tabell 2) er å opparbeide et tillitsforhold til pasienten. Ifølge sykepleierne oppnås et tillitsforhold ved å vise respekt, være ydmyk, åpen og lydhør for innspill fra pasienten for å få et samarbeid med pasienten og for å bygge et tillitsforhold.

\section{$\equiv$ «De gir uttrykk for at det er viktig å vise ydmykhet, slik at de kan bruke kunnskapen på en riktig måte til pasientens beste.»}

Sju av sykepleierne/informantene bruker begrepet ydmykhet, og det å være ydmyk i forhold til pasienter. Sykepleierne presiserer at for å lære av pasienter må en være ydmyk i forhold til kunnskapen, erfaringene og opplevelsene som pasientene har.

De gir uttrykk for at det er viktig å vise ydmykhet, slik at de kan bruke kunnskapen på en riktig måte til pasientens beste. Informantene presiserer at når de vet hva som er viktig for pasienten, kan de begynne å informere pasienten og hjelpe han til realistiske mål ut fra en helhetlig tenkning og vurdering av pasientens situasjon. 


\section{En sykepleier forteller om å være ydmyk}

En sykepleier beskriver det slik:

«En er involvert i andres liv, og noen ganger er det som om livet stopper opp. Det handler om fødsel, sykdom, krise, sorg og død. Vi står midt oppi det. En blir så ydmyk. Jo mer en jobber med slike situasjoner, dess mer ydmyk blir en for å få lov til å være nær andre mennesker i slike settinger. En har syn, hørsel og alle sanser åpne, og hvor øyeblikket betyr noe. Det er slik jeg lærer i pasientsituasjoner.»

Sitatet speiler det unike ved å være klinisk, utøvende sykepleier. Det finnes ikke noe fasitsvar på hvordan en bør møte slike situasjoner. Sykepleiernes forståelse av ydmykhet harmonerer med forskningen på opphavet til begrepet og den oppsummerende definisjonen: « ... a willingness to hold power in service of others» (12, S. 24).

\section{三 «Sykepleierne synes at det er vanskelig å kalle seg ekspertsykepleier.»}

Sykepleierne er avhengige av et gjensidig tillitsforhold til pasienten for å gjøre en best mulig jobb $(3,5)$. Ydmykheten kom også til uttrykk ved at flere av sykepleierne mener at de ikke er ekspert på alle områder.

Det kan være en av årsakene til at sykepleierne synes at det er vanskelig å kalle seg ekspertsykepleier, selv om de under intervjuene resonnerte, prioriterte og faglig begrunnet komplekse situasjoner som en ekspert og en gjenkjenner ekspertnivået til Benner (8). Alle sykepleierne var svært opptatte av at pasienten er ekspert i sitt eget liv og som de kan lære av.

\section{Veiledning bidrar til egenutvikling}

Gjennom intervjuene gir sykepleierne uttrykk for at deltakelse i en systematisk sykepleiefaglig veiledningsgruppe med refleksjon, sammen med kolleger, er et svært betydningsfullt kompetansetiltak. En informant uttrykker seg slik: 
«Vi har en veldig sårbar pasientgruppe som har stort behov for samtaler. Du skal være der og ta imot og være container. Det kan være ganske tøft og det er et veldig fokus på det å være til stede. Derfor er det viktig å være bevisst på å sortere og skille hva som er pasientens og hva som er mitt. Hvis en skulle ta alt innover seg, tror jeg ikke en ville orke å jobbe med denne typen pasientomsorg over tid. Sykepleiefaglig veiledning er et viktig verktøy for å få veiledning på hvordan man kan klare å skille. Det å ha fokus på nærhet og avstand. Det er en sånn type veiledning alle kliniske sykepleiere burde ha.»

Deltakelse i en sykepleiefaglig veiledningsgruppe er vesentlig for egenutviklingen, for klinisk yrkesutøvelse og for den sykepleieren de er i dag. I tillegg er sykepleiefaglig veiledning i grupper betydningsfullt for utviklingen av faglig og etisk læring, handlingsberedskap og utvikling av handlingskompetanse, ifølge sykepleierne.

\section{Behovet for veiledning er todelt}

Funn i studien synliggjør at behovet sykepleierne har knyttet til å delta i en sykepleiefaglig veiledningsgruppe er todelt. Det første handler om det faglige. Det andre handler om behovet sykepleierne har for å få tilbakemeldinger, støtte og å bli ivaretatt både som sykepleier og menneske i utfordrende situasjoner.

De fleste av sykepleierne $\varnothing$ nsker å delta i sykepleiefaglige veiledningsgrupper med refleksjon, både ut fra faglige hensyn og av hensynet til seg selv som sykepleier og som menneske. Under sykepleierstudiet og i de første årene som nyutdannede sykepleiere hadde flere erfaringer med deltakelse i sykepleiefaglige veiledningsgrupper.

Gjennom flere år har sykepleierledere og sykepleiere hatt kunnskap om betydningen av sykepleiefaglig veiledning for sykepleieres opplevelse av mestring, trivsel, tilfredshet i arbeidet og stabilitet i sykepleiergruppen (13).

\section{Yrket kan være en påkjenning}

Uten den støtten som en faglig veiledningsgruppe kan være for sykepleiere, kan det resultere i at sykepleierne utsettes for medfølelsesutmattelse $(10,11)$. Det kan igjen føre til en prosess som leder til jobb-utbrenthet, men som kan forebygges gjennom organisert og systematisk sykepleiefaglig veiledning i grupper $(14,15)$. 


\section{«Sykepleiefaglig veiledning kan bidra til et godt arbeidsmiljø og god arbeidshelse.»}

Cavanagh og medarbeidere etterlyser strategier for forebygging av jobb-utbrenthet i en review (16). Dette viser relevansen av vår studie knyttet til faktorer for forebygging av medfølelsesutmattelse. Sykepleiefaglig veiledning kan bidra til et godt arbeidsmiljø og god arbeidshelse, som er vesentlig for å gjøre en god jobb som sykepleier (17).

\section{Konklusjon}

Hva kan vi lære av sykepleiernes erfaringer? Studien viser at praksisfellesskapet er en viktig arena for læring og kompetanseutvikling for sykepleiere på alle kompetansenivåer og for erfarne sykepleiere når de gis mulighet til å reflektere over eget arbeid i sykepleiefaglige veiledningsgrupper.

Skal arbeidsplassen være en læringsarena betinger det faglig engasjerte kolleger i et st $\varnothing$ ttende arbeidsmilj $\varnothing$. Studien viser at sykepleiefaglig veiledning i refleksjonsgrupper er et betydningsfullt tiltak både for sykepleierstudenter og for klinisk utøvende sykepleiere på alle kompetansenivåer.

Studiens implikasjoner for sykepleierutdanning og klinisk praksis viser at sykepleiefaglig veiledning i refleksjonsgruppe bør være et kompetansetiltak.

\section{Referanser}

1. Thidemann I-J. Det kliniske studiet - sykepleierstudiet. Hvordan bør sykepleierstudiet tilrettelegges for at studentene, i sin læringsprosess, skal oppleve størst mulig grad av faglig kontinuitet og progresjon. En deskriptiv, longitudinell unders $\varnothing$ kelse. Høgskolen i Agder: 1997. Skriftserien nr. 23.

2. Thidemann I-J. Grunnleggende stell og pleie bør komme først. Tidsskriftet Sykepleien. 1997;15:48-51.

3. Thidemann I-J. Vi bare tar oss av hverandre. Tidsskriftet Sykepleien. 2002;90(19):42-6.

4. Thidemann I-J. Er teori nyttig? Tidsskriftet Sykepleien. 2005;93(0):61-2. 
5. Thidemann I-J. Den sårbare læringsarenaen - om praksisfellesskapets implikasjoner for sykepleieres læring og kompetanseutvikling. Vård i Norden. 2005;25(1):10-5.

6. Graneheim UH, Lundman B. Qualitative content analysis in nursing research: concepts, procedures and measures to achieve trustworthiness. Nurse Education Today. 2004;24(2):105-12. DOI: 10.1016/j.nedt.2003.10.001

7. Lai L. Strategisk kompetanseledelse. 3. utg. Bergen: Fagbokforlaget; 2013 .

8. Benner P. Fra novise til ekspert: dyktighet og styrke i klinisk sykepleiepraksis. Oslo/København: TANO Forlag i samarbeid med Munksgaard; 1995.

9. Lave J, Wenger E. Situated learning: legitimate peripheral participation. Cambridge: Cambridge University Press; 1991.

10. Adams RE, Boscarino JA, Figley CR. Compassion fatigue and psychological distress among social workers: A validation study. American Journal of Orthopsychiatry, 2006;76(1):1038. DOI: $\underline{10.1037 / 0002-9432.76 .1 .103}$

11. Figley CR. Compassion fatigue as secondary traumatic stress disorder: An overview. I: Figley CR, red. Compassion fatigue: Coping with secondary traumatic stress disorder in those who treat the traumatized. New York: BrunnerRoutledge; 2013: S.1-31.

12. Dickson J. Humilitas: A lost key to life, love, and leadership. Michigan: Zondervan; 2011.

13. Naper $\varnothing$, Hoffart R-A, Vråle GB. Veiledning - avgjørende for trivsel og mestring. Tidsskriftet Sykepleien. 2000;10:55-8.

14. Bang S. Rørt, rammet og rystet. Faglig vekst gjennom veiledning. Oslo: Gyldendal Norsk Forlag; 2003.

15. Hoffart R-AR, Larsen SH, Rø KI. Hjelper utbrente sykepleiere. Veiledningskurs for utbrente sykepleiere minsket stress og $\varnothing$ kte arbeidslysten. Tidsskriftet Sykepleien. 2014;102(2):46-8. DOI: 10.4220/sykepleiens.2014.0015 
16. Cavanagh N, Cockett G, Heinrich C, Doig L, Fiest K, Guichon JR, et al. Compassion fatigue in healthcare providers: A systematic review and meta-analysis. Nurs Ethics. 2020;27(3)639-65. DOI: 10.1177/0969733019889400

17. Almvik TN, Vråle GB. Sykepleiefaglig veiledning kan gi bedre helse og $\varnothing \mathrm{kt}$ trivsel. Tidsskriftet Sykepleien.

2019:107(75095) (e-75095). DOI:

10.4220/Sykepleiens.2019.75095 